\title{
CREATING A SUSTAINABLE AND DESIRABLE FUTURE
}

Insights from 45 global thought leaders 
This page intentionally left blank 

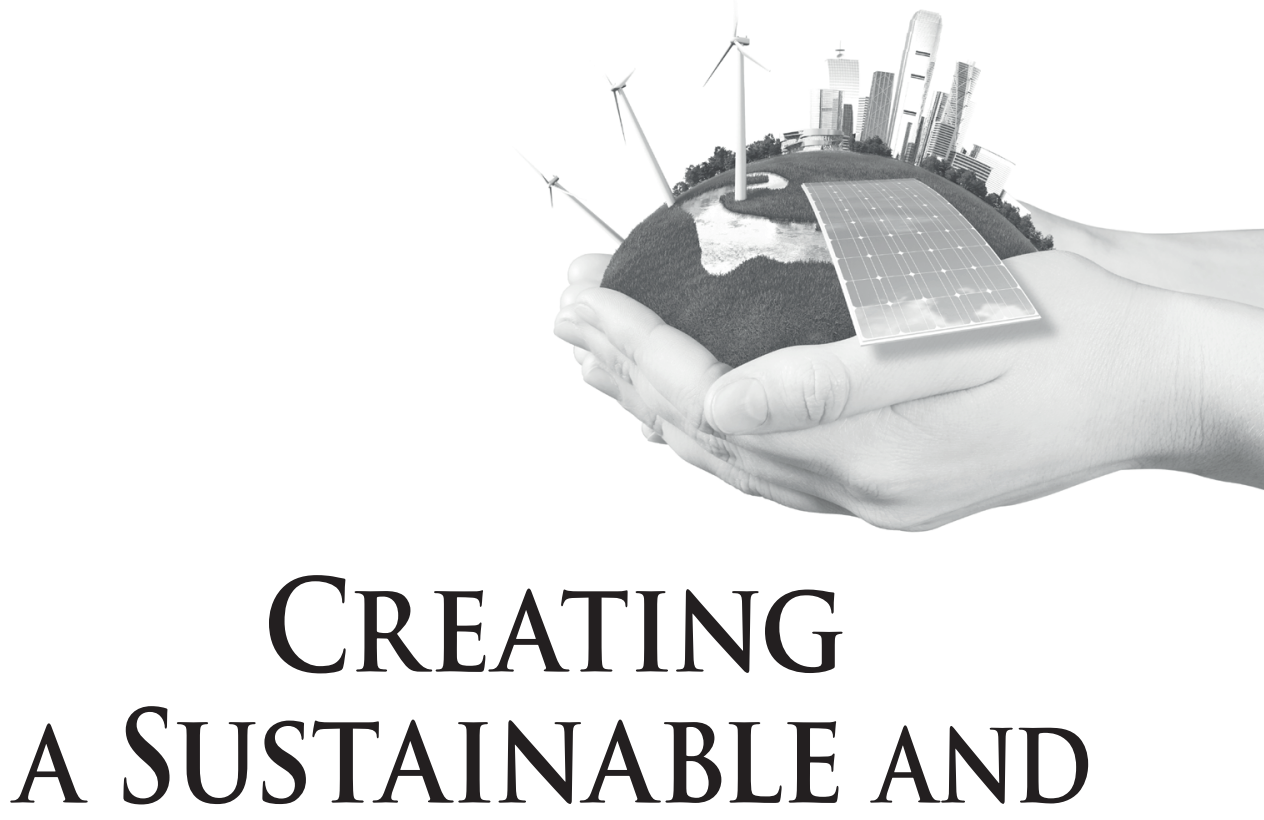

DESIRABLE FUTURE

Insights from 45 global thought leaders

\author{
Editors \\ Robert Costanza \\ Ida Kubiszewski \\ Crawford School of Public Policy \\ The Australian National University
}


Published by

World Scientific Publishing Co. Pte. Ltd.

5 Toh Tuck Link, Singapore 596224

USA office: 27 Warren Street, Suite 401-402, Hackensack, NJ 07601

UK office: 57 Shelton Street, Covent Garden, London WC2H 9HE

\section{Library of Congress Cataloging-in-Publication Data}

Creating a sustainable and desirable future : insights from 45 global thought leaders / [edited] by Robert Costanza \& Ida Kubiszewski (Australian National University, Australia). pages $\mathrm{cm}$

Includes bibliographical references and index.

ISBN 978-9814546881

1. Sustainable development. 2. Sustainability. 3. Environmentalism. 4. Environmental policy.

I. Costanza, Robert. II. Kubiszewski, Ida.

HC79.E5C725 2014

$338.9^{\prime} 27--\mathrm{dc} 23$

2013035772

\section{British Library Cataloguing-in-Publication Data}

A catalogue record for this book is available from the British Library.

Copyright $(2014$ by World Scientific Publishing Co. Pte. Ltd.

All rights reserved. This book, or parts thereof, may not be reproduced in any form or by any means, electronic or mechanical, including photocopying, recording or any information storage and retrieval system now known or to be invented, without written permission from the publisher.

For photocopying of material in this volume, please pay a copying fee through the Copyright Clearance Center, Inc., 222 Rosewood Drive, Danvers, MA 01923, USA. In this case permission to photocopy is not required from the publisher.

In-house Editors: Lum Pui Yee/Chitralekha Elumalai

Typeset by Stallion Press

Email: enquiries@stallionpress.com

Printed in Singapore 


\section{Contents}

Preface $\quad$ xi

Acknowledgments xiii

About the Editors $\quad \mathrm{xV}$

About the Contributors xvii

Part 1: Introduction 1

Chapter 1 Why We Need Visions of a Sustainable and Desirable World 3

Robert Costanza and Ida Kubiszewski

Chapter 2 Envisioning a Sustainable World

Donella Meadows

Chapter 3 Why Everyone Should Be a Futurist?

William S. Becker

Chapter 4 Think Like an Ecosystem, See Solutions

Frances Moore Lappé

\section{Part 2: Future Histories: Descriptions of a Sustainable and Desirable Future and How We Got There}

Chapter 5 What Would a Sustainable and Desirable

Economy-in-Society-in-Nature Look Like?

Robert Costanza, Gar Alperovitz, Herman Daly,

Joshua Farley, Carol Franco, Tim Jackson, Ida Kubiszewski, Juliet Schor, and Peter Victor 
Chapter 6 Vision Statement for the Planet in 2050

Ajay Bhave, Silvia Ceausu, Anand Deshmukh, Jessica Jewell, Wayne Pan, and Jana Timm

Chapter 7 Scenes from the Great Transition

Paul D. Raskin

Chapter 8 Environmental History Exam 2052:

The Last Half-Century

Les W. Kuzyk

Chapter 9 A Virtual Visit to a Sustainable 2050

Robert Costanza

Chapter 10 Reflections on a Life Lived Well and Wisely Joshua Farley

Chapter 11 The Great Turnaround: How Natural Capital Entered the Economy?

Ronald Colman

Chapter 12 How New Zealand Became a Green Leader? John Peet

Chapter 13 The New New York: 2050

Barbara Elizabeth Stewart

Part 3: Pieces of the Puzzle: Elements of the World We Want

Chapter 14 Sustainability and Happiness: A Development Philosophy for Bhutan and the World Jigmi Y. Thinley

Chapter 15 Flourishing as a Goal of International Policy

Martin Seligman

Chapter 16 What Else?

Wendell Berry

Chapter 17 Let Us Envision Gender Equality: Nothing

Else is Working

Jane Roberts

Chapter 18 Another World: Finally Her(e)

Kavita N. Ramdas and Jamie Querubin 
Chapter 19 Policy Reform to 350

Bill McKibben

Chapter 20 The Great Transition to 350

Dylan Walsh and Tess Croner

Chapter 21 On Baselines That Need Shifting

Daniel Pauly

Chapter 22 The Future of Roads: No Driving, No Emissions, Nature Reconnected

Richard T. T. Forman and Daniel Sperling

Chapter 23 The New Security

Gary Hart

Chapter 24 Green Accounting: Balancing Environment and Economy

Peter Bartelmus

Chapter 25 A Vision of America the Possible

James Gustave Speth

Part 4: Getting There

Chapter 26 The Way Forward: Survival 2100 William E. Rees

Chapter 27 An Integrating Story for a Sustainable Future 201 Mary Evelyn Tucker and Brian Thomas Swimme

Chapter 28 It Is Time to Fight the Status Quo Bill McKibben

Chapter 29 Can We Avoid the Perfect Storm? David W. Orr

Chapter 30 Sustainable Shrinkage: Envisioning a Smaller, Stronger Economy

Ernest Callenbach

Chapter 31 How to Apply Resilience Thinking: In Australia and Beyond?

Brian Walker 
Chapter 32 Endangered Elements: Conserving the Building Blocks of Life

Penny D. Sackett

Chapter 33 Well-Being, Sufficiency, and Work-Time Reduction Anders Hayden

Chapter 34 Millennium Consumption Goals (MCGs) at Rio+20: A Practical Step Toward Global Sustainability

Mohan Munasinghe

Chapter 35 Happiness and Psychological Well-Being: Building Human Capital to Benefit Individuals and Society

George W. Burns

Chapter 36 Time for a Bold Vision: A New, Green Economy Van Jones

Chapter 37 A World That Works for All

L. Hunter Lovins

Chapter 38 Fighting Poverty by Healing the Environment Christine Loh

Chapter 39 Re-Engineering the Planet: Three Steps to a Sustainable Free-Market Economy

Eckart Wintzen

Chapter 40 Raising Gross National Happiness through Agroforestry

Pahuna Sharma-Laden and Croix Thompson

Chapter 41 Building Bridges between Science and Policy to Achieve Sustainability

Katherine Richardson and Ole Waver

Chapter 42 Bringing Mozart to the Masses: Venezuela's

Music Revolution

Maria Páez Victor

Chapter 43 Creating the Schools of the Future: Education for a Sustainable Society 
Chapter 44 A Values-Based Set of Solutions for the Next Generation

Tim Kasser

Chapter 45 Teaching a University Course in Sustainable

Happiness

Catherine O'Brien

Chapter 46 The Time Has Come to Catalyze a Sustainable Consumerism Movement

Peggy Liu

Index 
This page intentionally left blank 


\section{Preface}

As a society, we need to think more deeply and discuss more broadly the kind of world we really want. This book is an attempt to deepen and broaden that discussion. It is a collection of positive ideas about what a sustainable and desirable future might look like from a broad range of perspectives.

In the environmental community, there is a growing pessimism about the future. Climate disruption, biodiversity loss, overpopulation, and a host of other problems seem to be getting far worse with no sign of our ability to solve them. The majority of the business and political communities are still in denial about the severity of the problems. They are counting on the ability of "business-as-usual" (with perhaps some tweaking) to solve them. But, as Paul Raskin has said: "It is business-as-usual that is the utopian fantasy."

This book is not about business-as-usual. It is not about projections of future technologies or extrapolations of past trends. It is a collection of multifaceted descriptions of better worlds that are both plausible and possible. These are not predictions of what will happen, but visions of what could happen if we, as a society, put our minds to it.

Most of the chapters are versions of articles that have been published in Solutions (www.thesolutionsjournal.com), which has a regular section that challenges authors to envision a future society in which all the correct changes have been made. Think of it as a "best of" collection of Solutions' visions plus a few additional chapters from other sources. The chapters are written in a broad range of styles. We see that as an advantage. Describing the future we want must take many forms. We hope the reader will find in these chapters inspiration, hope, and motivation to help envision and then create a better world. 
This page intentionally left blank 


\section{Acknowledgments}

We thank, first and foremost, all the contributing authors for their visions, for sharing those visions with the world, and for supporting Solutions. We also thank Sung Lee and the Crawford School of Public Policy at Australian National University for their encouragement and support in putting this collection together, and Ms Chitralekha Elumalai and Ms Lum Pui Yee, editors at World Scientific for their advice and help throughout the process. Finally, we thank the late Dana Meadows and dedicate this collection to her, for her inspiration, strength, and personal vision of a better world.

Robert Costanza

Ida Kubiszewski

Canberra, Australia, 2013 
This page intentionally left blank 


\section{About the Editors}

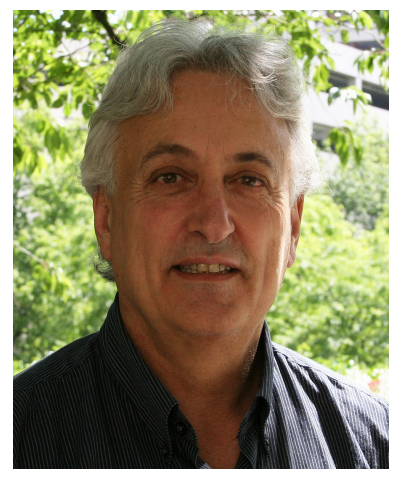

Dr Robert Costanza is a Professor and Chair in Public Policy at the Crawford School of Public Policy, Australian National University. Prior to this, he was Distinguished University Professor of Sustainability, in the Institute for Sustainable Solutions at Portland State University (2010-2012), Gund Professor of Ecological Economics and Founding Director of the Gund Institute for Ecological Economics at the University of Vermont (2002-2010), Professor at the University of Maryland (1988-2002) and at Louisiana State University (1980-1988). His transdisciplinary research integrates the study of humans and the rest of nature to address research, policy, and management issues at multiple time and space scales, from small watersheds to the global system. He is cofounder of the International Society for Ecological Economics and founding editor-in-chief of Solutions (www.thesolutionsjournal.org). He is author or coauthor of over 500 articles and 24 books and has been named one of ISI's Highly Cited Researchers since 2004. More than 200 interviews and reports on his work have appeared in various popular media. 


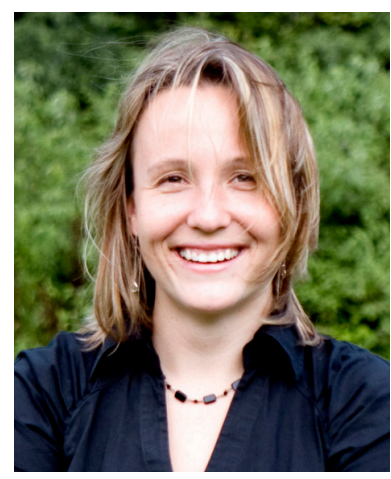

Dr Ida Kubiszewski is a Senior Lecturer at the Crawford School of Public Policy at Australian National University. Prior to this, she was an Assistant Research Professor and Fellow at the Institute for Sustainable Solutions, at Portland State University. She is the Managing Editor of a magazine/journal hybrid called Solutions (www.thesolutionsjournal.org). She is also a cofounder and former Managing Editor the Encyclopedia of Earth (www.eoearth.org). Dr Kubiszewski is the author or coauthor of over a dozen scientific papers. She is a Fellow at the National Council for Science and the Environment and an Associate Research Fellow at the Institut Veblen pour les réformeséconomiques (Veblen Institute for Economic Reforms). She sits on the steering committees or advisory boards of various organizations including the Ecosystem Service Partnership and the Environmental Information Coalition. 


\section{About the Contributors}

Gar Alperovitz Lionel R. Bauman Professor of Political Economy at the University of Maryland, is the cofounder of the Democracy Collaborative. $\mathrm{He}$ is the author of numerous books, including most recently What Then Must We Do? Straight Talk About the Next Revolution; America Beyond Capitalism; and, with Lew Daly, Unjust Deserts. He is a founding board member of the New Economics Institute and of the Committee for the Political Economy of the Good Society (PEGS). Alperovitz previously served as a legislative director in the US House of Representatives and the US Senate, and as a special assistant in the Department of State.

Peter Bartelmus is an honorary professor of the Bergische Universität Wuppertal, Germany. At the UN Environment Programme in Nairobi and the UN headquarters in New York, he developed international systems of environmental statistics and accounting. His latest book is the forthcoming Sustainability Economics: An Introduction.

William S. Becker is an executive director of the Presidential Climate Action Project (PCAP). PCAP has created a comprehensive plan for the Obama administration to shape US energy and climate policy. Becker also directs the Future We Want, which uses cuttingedge communication technologies to help the American people envision life in a sustainable, lowcarbon society. $\mathrm{He}$ is the former central regional director for the US Department of Energy.

Wendell Berry is the author of more than 40 works of fiction, nonfiction, and poetry and has been the recipient of numerous awards and honors. His books include Hannah Coulter (2004), Citizenship Papers (2005), The Way of Ignorance (2006), and Given: Poems (2005). Berry's latest works include The Mad Farmer Poems (2008) and Whitefoot (2009). He lives 
and works with his wife, Tanya Berry, on their farm in Port Royal, Kentucky.

Ajay Bhave did his Bachelors and Masters in Environmental Sciences in India. He was a research associate at the Department of Environmental Sciences, University of Pune for a year, wherein he worked on solute transport in coastal aquifers and in river processes. His interest in policy making led him to join the Masters program in Environmental Science, Policy and Management. He is currently at the International Institute for Industrial Environmental Economics, in Lund University. His research interests include implementation and consequent effects of biofuel program, corporate social responsibility, and sustainability. His interests also involve social entrepreneurship and its importance in community development.

George W. Burns is adjunct professor of psychology at Cairnmillar Institute, Melbourne; adjunct senior lecturer at Edith Cowan University, Perth; and director of the Milton H. Erickson Institute of Western Australia. He is a clinical psychologist and therapist trainer who teaches internationally, and his numerous publications include his recent book, Happiness, Healing, Enhancement.

Ernest Callenbach's novel Ecotopia, a portrait of an ecologically sustainable future society, has sold almost a million copies and was translated into nine languages. His most recent book is Ecology: A Pocket Guide, a nontechnical guide to 65 fundamental ecological terms. Callenbach passed away in 2012 .

Silvia Ceausu holds a bachelor degree in ecology and a master degree in systems ecology and sustainable development. Currently, she is studying at IIIEE in Lund as part of the MESPOM program. Her interests include environmental politics and policies, and the influence of mass-media in shaping environmental concepts.

Ronald Colman is founder and executive director of GPI Atlantic, a nonprofit research group dedicated to developing comprehensive accounts 
and measures of well-being and sustainable development. Since 2003 Colman has worked closely with the Royal Government of Bhutan to develop a national survey and measures of progress in line with that country's policy of integrating social, economic, ecological, and governance objectives.

Robert Costanza is a Chair of Public Policy at the Crawford School of Public Policy at Australian National University. He has authored or coauthored over 350 scientific papers, and reports on his work have appeared in Newsweek, U.S. News and World Report, The Economist, The New York Times, Science, Nature, National Geographic, and National Public Radio.

Tess Croner is pursuing a master's degree at the Yale School of Forestry and Environmental Studies. She graduated in 2009 with honors from Washington University in St Louis, where she earned a BA in environmental studies with a minor in anthropology.

Herman E. Daly is currently Professor at the University of Maryland. From 1988 to 1994, he was Senior Economist in the Environment Department of the World Bank. His interest in economic development, population, resources, and environment has resulted in over a hundred articles in professional journals and anthologies, as well as numerous books. In 1996, he received Sweden's Honorary Right Livelihood Award and the Heineken Prize for Environmental Science awarded by the Royal Netherlands Academy of Arts and Sciences. In 2002, he was awarded the Medal of the Presidency of the Italian Republic.

Anand Deshmukh obtained his Masters in Environmental Management from Shivaji University Kolhapur, India. His area of interests are Environmental impact assessment, corporate social responsibility, technology transfer and its role in climate change adaptation, industrial ecology for sustainable industry network, energy efficiency, and security. Currently, he is a student at the International Institute for Industrial Environmental Economic on the Erasmus Mundus Masters in Environmental Sciences Policy and Management program. 
Joshua Farley is an ecological economist, associate professor in Community Development \& Applied Economics, and fellow at the Gund Institute for Ecological Economics at the University of Vermont. His broad research interests focus on the design of economic institutions capable of balancing what is biophysically possible with what is socially, psychologically, and ethically desirable.

Richard T.T. Forman is the PAES Professor of Landscape Ecology at Harvard University, and teaches ecological courses in the Graduate School of Design and Harvard College. As a leader in landscape ecology, road ecology, and urban ecology, he links science with spatial patterns to interweave nature and people on the land. His books include Land Mosaics (1995), Road Ecology (2003), and Urban Regions (2008).

Carol Franco Dr Franco supports projects on forest mapping and monitoring and fosters climate change policies in Latin America. Her research has focused on environmental and socioeconomic policies, food security, and climate change policies. She has worked as the Carbon Finance Officer of the United Nations Development Program in the Dominican Republic, and prior to joining the Center, she was a Research Assistant Professor at the Institute for Sustainable Solutions at Portland (OR) State University. Dr Franco received her Ph.D. from the State University of New York (SUNY) College of Environmental Science and Forestry.

Gary Hart Former US senator Gary Hart served on the Armed Services committee, was a founder of the Congressional Military Reform caucus, and is currently chair of the American Security Project. He is chair of the Threat Reduction Advisory Council at the Department of Defense. Hart was cochair of the US Commission on National Security for the Twentyfirst Century. The commission performed the most comprehensive review of national security since 1947, predicted the terrorist attacks on America, and proposed a sweeping overhaul of US national security structures and policies. Gary Hart represented the state of Colorado in the United States Senate from 1975 to 1987 . In 1984 and 1988, he was a candidate for his party's nomination for president. 
Anders Hayden is an assistant professor of political science at Dalhousie University, Nova Scotia. His primary research interest is the social and political responses to climate change, particularly the evolving balance between efforts to promote green growth and sufficiency-based challenges to the endless growth of production and consumption. He is the author of Sharing the Work, Sparing the Planet: Work Time, Consumption and Ecology.

Tim Jackson is a leading international expert on sustainability. Since 2000, he has been professor of sustainable development at the University of Surrey - the first such chair to be created in the UK. In 2004, he was appointed as economics commissioner on the UK Sustainable Development Commission, where he led a five-year project called Redefining Prosperity. This groundbreaking work culminated in the publication of his controversial book Prosperity without Growth-Economics for a Finite Planet.

Jessica Jewell's research focuses on energy security under long-term energy scenarios and as a driver for policy change. More broadly, she is interested in the interaction between national energy priorities and global energy objectives. She works in the Energy Program at the International Institute for Applied Systems Analysis.

Van Jones is president and cofounder of Rebuild the Dream, a platform for bottom-up, people-powered innovations to help fix the US economy. In 2008, Fast Company magazine said he had one of the 12 most creative minds on earth, and in 2009 Time magazine named him one of the 100 most influential people in the world. That same year he worked as the green jobs advisor to the Obama White House, where he helped run the interagency process that oversaw US $\$ 80$ billion in green energy recovery spending.

Tim Kasser is professor of psychology at Knox College in Illinois. He has published numerous articles, chapters, and books on values, goals, quality of life, and environmental sustainability. Kasser also frequently consults with activist and civil society organizations in the United States and United Kingdom. 
Ida Kubiszewski is a senior lecturer at the Crawford School of Public Policy at Australian National University. She is the managing editor of Solutions and cofounder and former managing editor of the Encyclopedia of Earth. Kubiszewski is the author or coauthor of dozens of scientific papers and a fellow at the National Council for Science and the Environment.

Les W. Kuzyk is currently employed in urban planning in Western Canada, with a recent focus on sustainability research. He has authored several articles including two academic papers promoting the use of the ecological footprint. He is seeking to further a parallel freelance writing career through the composition, now in progress, of a novel.

Frances Moore Lappé is author of 18 books, including the three-millioncopy Diet for a Small Planet. She is cofounder of Food First: The Institute for Food and Development Policy; and, more recently, with Anna Lappé, of the Small Planet Institute and the Small Planet Fund. In 2007, Gourmet magazine named her one of 25 people, including Thomas Jefferson and Julia Child, whose work has changed the way America eats.

Peggy Liu is chairperson of the Joint US-China Collaboration on Clean Energy (JUCCCE), a nonprofit with the goal of greening China for a healthier world. She was named a TIME Hero of the Environment and is an executive advisor to the Marks \& Spencer department store on issues of sustainability. She has also been dubbed China's "green goddess" and in March 2012 was named by China Business News as one of the 50 Most Innovative Business Leaders.

Christine Loh is founder and CEO of the nonprofit think tank Civic Exchange, based in Hong Kong. A lawyer by training and a commodities trader by profession, she was previously a highly successful litigator in Hong Kong for nearly 10 years.

L. Hunter Lovins is president of Natural Capitalism Solutions, which helps companies, communities, and countries implement more sustainable business practices profitably. Over her 30 years as a sustainability thought leader, Lovins has written hundreds of articles and 13 books. A founder of 
the field of sustainable management, she has helped create several MBA programs and currently teaches sustainable business at the Bainbridge Graduate Institute, the University of Denver, and Bard College.

Bill McKibben is author of a dozen books about the environment, beginning with The End of Nature (1989), regarded as the first book for a general audience on climate change. He is a founder of the grassroots climate campaign 350. org, which has coordinated 15,000 rallies in 189 countries since 2009. The Boston Globe said in 2010 that he was "probably the country's most important environmentalist."

Donella Meadows, founder of the Sustainability Institute, was a professor at Dartmouth College, a long-time organic farmer, a journalist, and a systems analyst. She was honored both as a Pew Scholar in Conservation and Environment and as a MacArthur Fellow. Her weekly column, "The Global Citizen," in which she commented on world events from a systems point of view, appeared in more than 20 newspapers and was nominated for a Pulitzer Prize in 1991. Meadows passed away in the spring of 2001.

Mohan Munasinghe is chairman of the Munasinghe Institute of Development and holds professorships at universities around the world. He shared the 2007 Nobel Peace Prize as vice chairman of the UN Intergovernmental Panel on Climate Change. Highlights from 40 years of distinguished public service include working as senior energy advisor to the president of Sri Lanka, advisor to the US Council on Environmental Quality, and senior advisor/manager at the World Bank.

Catherine O'Brien is associate professor in the Education Department of Cape Breton University, Nova Scotia. She coined the term "sustainable happiness" at the Second International Conference on Gross National Happiness in 2005. In addition to the university course that she developed for Cape Breton University, O'Brien cocreated an online course on sustainable happiness for the general public.

David W. Orr is the Paul Sears Distinguished Professor of Environmental Studies and Politics, Oberlin College, and executive director of the 
Oberlin Project. He is the author of seven books, including Down to the Wire: Confronting Climate Collapse and Hope is an Imperative.

Wayne Pan is student in the Erasmus Mundus Master's of Environmental Sciences, Policy and Management programme and is currently studying at IIIEE in Lund University. He has worked as a strategic management consultant, a web and print designer, and as an editor in the UN system. $\mathrm{He}$ most recently spent time as a Communications and Advocacy Advisor at UNDP China. He has interests in issues surrounding consumption, sustainable cities, and public awareness/value changing. He has lived and worked in the US, Europe, and China. He holds a BA from UC Berkeley.

Daniel Pauly is a professor at the Fisheries Centre of the University of British Columbia. Since 1999, he has been principal investigator of the Sea Around Us Project, devoted to documenting and mitigating the impact of fisheries on the world's marine ecosystems.

John Peet is the author of Energy and the Ecological Economics of Sustainability as well as papers on systems, sustainability, and the ethical requirements of stakeholder involvement. Since retirement, he has worked with a number of local, national, and international nongovernment organizations.

Jamie Querubin A young civil servant who believes in the power of community engagement, civic participation, and a stronger, more effective government.

Kavita N. Ramdas served as president and CEO of the Global Fund for Women from 1996 to September 2010. This fall, she was appointed visiting scholar and fellow to Stanford University's Center for Democracy, Development, and the Rule of Law (CDDRL) and the Center for Philanthropy and Civil Society (PACS). She also chairs the Expert Working Group of the Global Leaders Council for Reproductive Health of the Aspen Institute.

Paul D. Raskin is president of the Tellus Institute. He founded Tellus in 1976, Stockholm Environment Institute - US in 1989, the Global 
Scenario Group in 1995, and the Great Transition Initiative in 2003. The overarching theme of his work has been envisioning and analyzing alternative scenarios of development, and identifying the strategies, policies, and values for a transition toward a future of environmental sustainability and human justice.

William E. Rees is a human ecologist, ecological economist, and professor emeritus and former director of the University of British Columbia's School of Community and Regional Planning. Best known as the originator and codeveloper of ecological footprint analysis, Rees has lectured on EFA and related topics in 25 countries. He has been recognized as one of British Columbia's top public intellectuals.

Katherine Richardson is professor of biological oceanography at the University of Copenhagen and leader of the Sustainability Science Centre. She was chairman of the Danish Commission on Climate Change Policy, which presented a 2010 roadmap for how Denmark can become independent of fossil fuels by 2050. She is also lead author of the book Climate Change: Global Risks, Challenges and Decisions. She was vice president of the European Science Foundation from 2001 through 2008.

Jane Roberts cofounded 34 Million Friends of the United Nations Population Fund in 2002. For this work, she has been recognized by the American Public Health Association, by MS Magazine, and by the United Nations Association. In 2005, she was one of 1000 women nominated for the Nobel Peace Prize as part of the 1000 Peace Women Project by UNESCO in Bern, Switzerland.

Penny D. Sackett is a physicist, astronomer, and former chief scientist for Australia (2008-2011). Sackett has held a research fellowship at the Princeton Institute for Advanced Study and appointments at the Kapteyn Astronomical Institute in the Netherlands and at the Australian National University.

Juliet Schor is professor of sociology at Boston College. Before joining Boston College, she taught at Harvard University for 17 years, in the 
Department of Economics and the Committee on Degrees in Women's Studies. Her research has focused on work, consumption, and sustainability. Her "work and spend" cycle is an integrated approach to production and consumption. Most recently, her research emphasizes political consumption, new patterns of time-use, and alternative economic structures. As a member of a MacArthur Research Network, she is studying the emergence of collaborative consumption.

Martin Seligman is the Zellerbach Family Professor of Psychology and director of the Positive Psychology Center at the University of Pennsylvania, where he focuses on positive psychology, learned helplessness, depression, ethnopolitical conflict, and optimism. He is a best-selling author of several books, including, most recently, Flourish. In 1996, Seligman was elected president of the American Psychological Association by the largest vote in modern history.

Peter M. Senge is a senior lecturer at the Massachusetts Institute of Technology and founding chair of the SoL (Society for Organizational Learning) Council. He is author of The Fifth Discipline: The Art and Practice of the Learning Organization and, most recently, The Necessary Revolution: How Individuals and Organizations are Working Together to Create a Sustainable World.

Pahuna Sharma-Laden works as the Asia regional manager for Trees for the Future. She worked previously as an environmental reporter and researched the impact of bamboo flowering in northeast India for the Center for Science and Environment, New Delhi.

Daniel Sperling is professor of civil engineering and environmental science and policy, and founding director of the Institute of Transportation Studies at the University of California, Davis, and holds the transportation seat on the California Air Resources Board. He is author or editor of over 200 papers and reports and 12 books, has served on 13 National Academies committees, recently chaired the Future of Mobility committee of the (Davos) World Economic Forum, and testified seven times to the US Congress on alternative fuels and advanced vehicle technology. 
James Gustave Speth is professor of law at the Vermont Law School. He is author of the forthcoming book America the Possible: Roadmap to a New Economy. In 2009, he completed his decade-long tenure as dean at the Yale School of Forestry and Environmental Studies. From 1993 to 1999, Speth was administrator of the UN Development Programme. Prior to this, he was founder and president of the World Resources Institute and chairman of the US Council on Environmental Quality under the Carter administration.

Barbara Elizabeth Stewart is a journalist, editor, and college teacher of writing and media studies. She has worked as a reporter for newspapers in Florida and New York, has written articles for the Guardian, The New York Times, and the Telegraph. She has taught in the City University of New York system, at Steven Institute of Technology. She is currently teaching media studies at Sherubtse College in Trashigang, which is part of the Royal Institute of Bhutan.

Brian Thomas Swimme is a professor at the California Institute of Integral Studies in San Francisco. He is coauthor of The Universe Story, the result of a 10-year collaboration with the cultural historian Thomas Berry.

Jigmi Y. Thinley The Honorable Lyonchhen Jigmi Y. Thinley is the first democratically elected prime minister of Bhutan. Prior to his election in 2008, he served as minister for Foreign Affairs and minister for Home and Cultural Affairs. He also served as prime minister from 1998 through 1999 and again from 2003 through 2004. The Honorable Y. Thinley is presently chairman of the National Environment Commission and the Ugyen Wangchuck Institute of Conservation and Environment.

Croix Thompson works as the Caribbean and West Africa regional manager for Trees for the Future. He previously worked for a television news station in Kansas City, Missouri, and served in the US Peace Corps in Niger.

Jana Timm is at the International Institute for Industrial Environmental Economics (IIIEE) Lund University. 
Mary Evelyn Tucker is a senior lecturer and research scholar at Yale University, where she has appointments in the School of Forestry and Environmental Studies, the Divinity School, the Department of Religious Studies, and the Center for Bioethics. She also directs the Forum on Religion and Ecology at Yale with her husband, John Grim.

Maria Páez Victor is a sociologist, born in Venezuela and educated in Caracas, New York, Mexico City, and Canada. For several years, she taught the sociology of health and medicine as well as health and environmental policies at the University of Toronto. Páez Victor has national and international experience in policy analysis and impact assessment, with expertise in the areas of health, environment, and energy.

Peter Victor is an economist who has worked on environmental issues for over 40 years as an academic, consultant, and public servant. Victor was one of the founders of the emerging discipline of ecological economics and was the first President of the Canadian Society for Ecological Economics. Peter Victor is a Professor in Environmental Studies at York University and from 1996 to 2001 was Dean of the Faculty of Environmental Studies. This followed several years as Assistant Deputy Minister of the Environmental Sciences and Standards Division in the Ontario Ministry of the Environment. Prior to that, Peter Victor was a principal of VHB Consulting and Victor and Burrell Research and Consulting where he undertook many influential policy-related economic studies in Canada and abroad. He has continued to provide technical advice in areas such as air pollution and health, emissions trading, emerging issues, and education for sustainable energy development.

Ole Wæver is professor of international relations at the University of Copenhagen and director of the Centre for Advanced Security Theory. He originated the concept of "securitization" and was a central figure in developing the Copenhagen School in security studies. Among his main books are Security: A New Framework for Analysis and Regions and Powers: The Structure of International Security. 
Brian Walker lectured at the University of Zimbabwe for six years and was professor of ecology at the University of the Witwatersrand, Johannesburg, until 1985, when he moved to Australia as chief of the Division of Wildlife and Ecology at CSIRO. He currently is a research fellow in the CSIRO Division of Ecosystem Science, chairs the board of the Resilience Alliance, is a fellow in the Beijer Institute for Ecological Economics in Sweden, and has a part-time appointment in the Stockholm Resilience Centre.

Dylan Walsh has a master's degree from Yale School of Forestry and Environmental Studies. He is currently an editor at Solutions.

Eckart Wintzen (1939-2008) was an unconventional Dutch entrepreneur and a pioneer in the field of sustainability. He built BSO/Origin, an IT company of 6000 employees with offices in 21 countries, and was one of the first to publish an annual environmental report. After selling his software business in 1996, Wintzen initiated Ex'tent Green Venture Capital. 